bloud of the one, the bodie of the other eaten with dogs: for the false accusing and killing of Naboth. So also hath God punished the same and the like sinnes in all after-times, and in these our daies by the same famine, plagues, warre, losse, vexation, death, sicknesse, and calamities, howsoeuer the wise men of the world raise these effectes no higher than to second causes, and such other accidents, which, as being next their eyes and eares, seeme to them to worke euery alteration that happeneth.

\title{
Ch. XX. Of Iehoram the sonne of Iehosaphat, and Ahazia
}

\section{Ch. XXI. Of Athalia}

\$6. A digression, wherein is maintained the libertie of vsing coniecture in Histories.

Thvs much concerning the person of Ioas, from whom, as from a new roote, the tree of Dauid was propagated into many branches. In handling of which matter, the more I consider the nature of this Historie, and the diuersitie beweene it and others, the lesse, me thinkes, I neede to suspect mine owne presumption, as deseruing blame, for curiositie in matter of doubt, or boldnesse in libertie of coniecture. For all Histories doe giue vs information of humaine counsailes and euents, as farre forth as the knowledge and faith of the writers can affoord; but of Gods will, by which all things are ordered, they speake onely at randome, and many times falsly. This we often finde in prophane writers, who ascribe the ill successe of great vndertakings to the neglect of some impious rites, whereof indeed God abhorred the performance as vehemêtly, as they thought him to be highly offended with the omission. Hereat we 